\title{
PENGARUH KOMPETENSI KOMITE AUDIT, KEPEMILIKAN MANAJEMEN DAN UKURAN DEWAN KOMISARIS TERHADAP KUALITAS LAPORAN KEUANGAN
}

\author{
WAHDAN ARUM INAWATI \\ MUHAMAD MUSLIH \\ KURNIA
}

Universitas Telkom, Jl. Telekomunikasi No. 1, Terusan Buahbatu - Bojongsoang, Sukapura, Bandung, Indonesia inawatiarum@gmail.com, muslih.moeztea@gmail.com, kurnia_m2@yahoo.com

\begin{abstract}
This research aims to determine the influence of audit committee competency, managerial ownership, and size board of financial statements quality. Financial statement quality in this research measured by relevance. The research method applied quantitative causality method. The object of research is the food and beverage subsector companies listed on Indonesia Stock Exchange in period 2015 - 2018. The sample of this research, which complied 8 samples with period of 4 years, so the data processed 32 data. The result of this research $62.1 \%$ independent variables can explain the quality of financial statements, while $37.9 \%$ is explained by other variables not included in this research. The audit committee competency variables, management ownership and the size of the board of commissioners have a simultaneous influence on the quality of financial statements. The audit committee competency variable has a negative effect while the size of the board of commissioners has a positive effect on the quality of financial statements partially. While management ownership has no influence on the quality of financial statements.
\end{abstract}

Keywords: Audit committee, managerial ownership, size board, financial statement quality

Abstrak: Penelitian ini bertujuan untuk mengetahui pengaruh kompetensi komite audit, kepemilikan manajemen, dan ukuran dewan komisaris terhadap kualitas laporan keuangan. Kualitas laporan keuangan dalam penelitian diukur dengan menggunakan proksi relevansi. Metode penelitian yang digunakan dalam penelitian ini adalah kuantitatif kausalitas. Objek penelitian dalam penelitian ini adalah perusahaan sub sektor makanan dan minuman yang terdaftar di Bursa Efek Indonesia periode 2015 - 2018. Sampel penelitian berjumlah 8 dengan runtut waktu 4 tahun sehingga data yang diolah sebanyak 32 data. Hasil pengujian dalam penelitian ini adalah terdapat $62,1 \%$ variabel independent dapat menjelaskan kualitas laporan keuangan, sedangkan 37,9\% dijelaskan oleh variabel lain yang tidak dimasukkan di dalam penelitian ini. Variabel kompetensi komite audit, kepemilikan manajemen dan ukuran dewan komisaris memiliki pengaruh secara simultan terhadap kualitas laporan keuangan. Variabel kompetensi komite audit memiliki pengaruh negatif sedangkan ukuran dewan komisaris memiliki pengaruh positif terhadap kualitas laporan keuangan secara parsial. Sementara kepemilikan manajemen tidak memiliki pengaruh terhadap kualitas laporan keuangan.

Kata kunci. Komite audit; kepemilikan manajemen; ukuran dewan; kualitas laporan keuangan 


\section{PENDAHULUAN}

Dalam teori keagenan (Jensen dan Meckling, 1976), terdapat dua pihak di dalam perusahaan yang memiliki kepentingan yang bertentangan. Pihak pertama disebut sebagai principal atau pemilik perusahaan dan pihak kedua disebut sebagai agent atau manajemen.

Pertentangan terjadi dikarenakan manajemen tidak menjalankan perintah pemilik perusahaan untuk kepentingannya sendiri. Laporan keuangan merupakan bentuk pertanggungjawaban manajemen kepada pemilik perusahaan dalam melakukan tugasnya. Informasi yang ada di dalam laporan keuangan dapat menjadi sinyal mengenai kondisi perusahaan bagi para penggunanya.

Peraturan OJK No. X.K.2 mengenai Penyampaian Laporan Keuangan Berkala Emiten atau Perusahaan Publik menjelaskan bahwa menyajikan dan mengungkapan laporan keuangan merupakan kewajiban manajemen yang harus dilakukan setiap periode. Laporan keuangan yang bermanfaat merupakan laporan yang berkualitas dan digunakan sebagai acuan dalam proses pengambilan keputusan. Kualitas laporan keuangan dapat diukur dengan beberapa proksi, salah satunya melalui karakteristik kualitatif laporan keuangan. Karakteristik kualitatif laporan keuangan secara rinci dijelaskan dalam SFAC (Statements of Financial Accounting Concepts) No. 2 Tahun 1980. Dalam SFAC No. 2, informasi akuntansi yang terdapat dalam laporan keuangan harus memiliki empat karakteristik kualitatif utama yaitu understandability (dapat dipahami), relevance (relevan), reliability (andal) dan comparability (dapat diperbandingkan). Penelitian ini akan berfokus pada karakteristik kualitatif primer yaitu relevance.

Suatu laporan keuangan dapat dianggap relevan (relevance) jika mampu membuat perbedaan dalam suatu keputusan sehingga dapat membantu pengguna untuk memprediksi kejadian masa lalu, sekarang dan masa depan; yaitu memiliki nilai prediktif (predictive value). Jika tidak mempengaruhi suatu keputusan, informasi tersebut tidak dapat dikatakan relevan. Selain nilai prediktif, dalam SFAC No. 2 dijelaskan bahwa informasi yang relevan juga harus memiliki nilai umpan balik (feedback value) yang membantu pengguna laporan keuangan mengoreksi ekspektasi masa lalu dan memiliki ketepatan waktu (timeliness). Informasi dapat mempengaruhi keputusan pengguna jika disampaikan di waktu yang tepat. Industri makanan dan minuman masih menjadi salah satu sektor manufaktur yang menjadi pilihan investor dalam berinvestasi. Hal ini dikarenakan sektor ini masih memberikan kontribusi yang besar terhadap pertumbuhan ekonomi nasional. Jika dilihat dari PDB Nasional tahun 2015-2018, PDB industri makanan dan minuman berada di atas PDB Nasional. Hal ini dapat dilihat dalam Gambar 1 sebagai berikut.

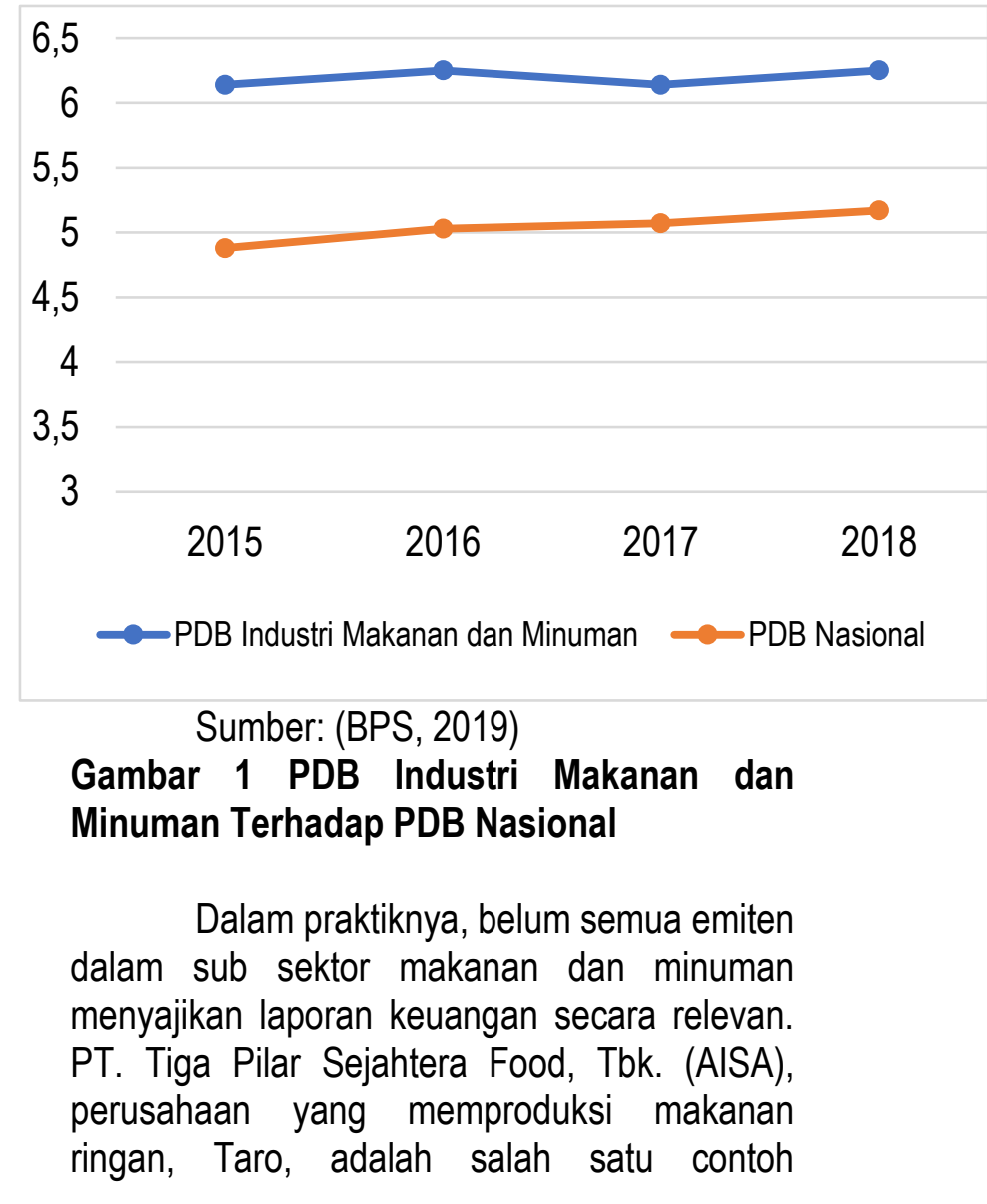


perusahaan tersebut. Laporan keuangan perusahaan di tahun 2017 ditolak oleh pemegang saham pada saat RUPS Tahunan. Investor menduga ada aliran dana kepada pihak ketiga yang tidak bisa dijelaskan oleh pihak manajemen. Investor meminta laporan keuangan perusahaan untuk dilakukan audit investigasi oleh auditor eksternal, pada saat itu KAP Ernst \& Young. KAP merilis laporan bahwa dana mencurigakan tersebut senilai Rp. 1,78 Triliun melalui berbagai skema, yaitu pencairan pinjaman, pencairan deposito berjangka, transfer dana di rekeing bank, dan pembiayaan beban pihak afiliasi oleh Grup AISA. Hal lain ditemukan bahwa transaksi dengan pihak terafiliasi tidak menggunakan mekanisme pengungkapan yang memadai kepada stakeholders secara relevan karena pencatatan keuangan yang dilakukan pihak internal perusahaan berbeda dengan yang digunakan auditor dalam proses mengaudit laporan keuangan tahun 2017 (Wareza, 2019).

Terdapat beberapa faktor yang dapat mempengaruhi kualitas laporan keuangan perusahaan. Pada penelitian ini digunakan faktor kompetensi komite audit, kepemilikan manajemen dan ukuran dewan komisaris dan pengaruhnya terhadap kualitas laporan keuangan, dengan menggunakan proksi relevansi laporan keuangan. Komite audit yang memiliki kompetensi adalah seseorang yang berpengalaman di bidang keuangan dan akuntansi, bersertifikasi akuntan atau comparable experience, atau memiliki posisi sebagai Chief Executive Officer (CEO) atau senior officer lainnya yang memiliki tanggung jawab pengawasan di bidang pengawasan keuangan (Blue Ribbon Committee dalam Putri, 2015). Menurut (Sakti, 2019), komite audit di dalam perusahaan yang memiliki kemampuan dalam bidang akuntansi dan keuangan dapat meningkatkan kualitas laporan keuangan dan mempercepat waktu pelaporan.

Faktor kedua adalah kepemilikan manajemen. Kepemilikan manajemen merupakan persentase kepemilikan saham yang dimiliki pihak manajemen (Harnida, 2015). Penelitian yang dilakukan oleh (Harnida, 2015) menyimpulkan bahwa kepemilikan manajemen memiliki pengaruh yang positif terhadap penyampaian waktu laporan keuangan. Semakin tinggi jumlah kepemilikan manajemen maka semakin perusahaan akan menyampaikan laporan keuangan dengan segera. Faktor terakhir adalah ukuran dewan komisaris. Dalam UU PT No. 40 Tahun 2007, dewan komisaris merupakan jumlah orang yang ada di dalam organ perusahaan yang memiliki tanggung jawab untuk melakukan pengawasan secara umum dan/atau khusus sesuai dengan anggaran dasar serta memberikan nasihat kepada direksi. Penelitian yang dilakukan oleh (Krismiaji \& Suhardjanto, 2016) serta (Milawati, Kustina, \& Dewi, 2018) menemukan bahwa ukuran Board Governance memiliki pengaruh yang positif terhadap relevansi informasi akuntansi. Relevansi informasi akuntansi yang digunakan dalam penelitian tersebut adalah predictive value. Semakin banyak Dewan Komisaris yang terlibat dalam melakukan control maka akan semakin relevan laporan keuangan yang disajikan kepada pengguna.

\section{Kualitas Laporan Keuangan}

Kartikahadi et al (2016:53) mengungkapkan bahwa laporan keuangan haruslah memenuhi $\mathrm{k}$ arakteristik kualitatif (qualitative characteristics) tertentu agar dapat memberikan informasi yang berguna bagi pemakai. Terdapat empat karakteristik kualitatif pokok yakni: (1) dapat dipahami (understandability), (2) relevan (relevance), (3) keandalan (reliability), dan (4) dapat diperbandingkan (comparability). Dalam penelitian ini menggunakan proksi relevansi laporan keuangan dalam mengukur kualitas laporan keuangan.

\section{Relevansi Laporan Keuangan}

Menurut Kartikahadi et al (2016:56), informasi yang bersifat penegasan (confirmatory) tentang peristiwa atau keadaan 
masa lalu dan masa kini, berkaitan dengan informasi yang diperlukan untuk meramalkan atau memproyeksikan (predictive) peristiwa atau keadaan masa depan. Informasi mengenai posisi keuangan dan kinerja yang dilaporkan dalam laporan keuangan perbandingan untuk dua tahun usaha, selain bermanfaat untuk pengambilan keputusan, pembayaran bonus manajemen dan dividen untuk para pemegang saham atas prestasi periode yang bersangkutan, juga berguna untuk melakukan analisis dan meramalkan perkembangan bisnis dan arus kas di masa depan.

Pengukuran relevansi dalam penelitian ini menggunakan Skala Qualitative Characteristics. Skala ini berisikan lima petanyaan yang disusun oleh Beest et. al (2009). Indeks ini memiliki skor maksimum 25 poin dan menggunakan Skala rasio. Setiap pertanyaan memiliki skor maksimum lima dan ada lima pertanyaan, dapat dilihat secara rinci dalam tabel 1 indeks skala pengukuran relevansi laporan keuangan adalah sebagai berikut:

$R E V=\frac{\text { Skor Perolehan }}{\text { Skor Maksimal (20) }}$

\section{Kompetensi Komite Audit}

Menurut Chrisdianto (2013) komite audit pada dasarnya mampu mendorong manajemen perusahaan untuk melakukan berbagai pengembangan berkaitan dengan upaya- upaya untuk memenuhi prinsip- prinsip Good Corporate Governance. Menurut Indriani dan Nurkholis dalam Chrisdianto (2013) ada beberapa hal yang perlu dipahami berkaitan dengan keanggotaan komite audit. Salah satunya adalah kompetensi komite audit. Kompetensi merupakan pemahaman yang memadai untuk memiliki oleh anggota komite audit. Anggota komite audit yang memiliki latar belakang pendidikan dan keahlian akuntansi keuangan dapat mengadopsi standar akuntabilitas dan tingkat prestasi yang tinggi (Chrisdianto, 2013).
Rumus untuk menghitung kompetensi komite audit adalah sebagai berikut:

Kompetensi Komite Audit $=$ Jumlah anggota yang berkompetensi di bidang audit/akuntansi (2) Jumlah anggota komite audit keseluruhan

\section{Kepemilikan Manajemen}

Struktur kepemilikan suatu perusahaan memiliki peran dalam menerapkan kebijakan perusahaan. Pihak yang memiliki proporsi kepemilikan yang lebih tinggi dibandingkan pihak yang lain akan dominan mempengaruhi kebijakan pemilihan metode akuntansi yang akan digunakan dalam perusahaan. Jao dan Pagalung (2011) berpendapat bahwa dengan adanya struktur kepemilikan maka dapat meminimalisir masalah agensi karena struktur kepemilikan mampu mempengaruhi jalannya perusahaan yang pada akhirnya berpengaruh pada kinerja perusahaan.

Jao dan Pagalung (2011) menyatakan bahwa penerapan corporate governance dapat dilakukan melalui mekanisme monitoring untuk menyelaraskan berbagai kepentingan antara lain: (1) mempebesar kepemilikan saham perusahaan oleh manajemen (managerial ownership) (Jensen dan Meckling, 1976) sehingga kepentingan pemilik atau pemegang saham dapat disejajarkan dengan kepentingan manajer. (2) kepemilikan saham oleh investor institusional. (3) melalui peran monitoring oleh Dewan Komisaris (Board of Directors). (4) membentuk Komite Audit sebagai pengawas perusahaan.

Rumus untuk menghitung kepemilikan manajemen adalah sebagai berikut:

Kepemilikan Manajemen $=$ Jumlah saham yang dimiliki Management (3)

Jumlah saham yang outstanding

\section{Ukuran Dewan Komisaris}

Dewan Komisaris merupakan organ utama yang penting di dalam perusahaan. KNKG (2006) memberikan definisi bahwa 
Dewan Komisaris merupakan pengendalian internal tertinggi yang bertanggung jawab secara kolektif untuk melakukan pengawasan dan memberikan penilaian atas tata kelola perusahaan yang dijalankan oleh Direksi. Dewan Komisaris dan Komite Audit memastikan bahwa perusahaan telah menjalankan Tata Kelola Perusahaan yang Baik (Good Corporate Governance) dalam setiap strategi dan program kerja yang dijalankan. Jumlah Dewan Komisaris akan mempengaruhi keputusan yang akan diambil. Rumus untuk menghitung ukuran dewan komisaris adalah sebagai berikut:

Ukuran Dewan Komisaris $=$ $\sum$ Dewan komisaris

(4)

Tabel 1 Indeks Skala Pengukuran Relevansi Laporan Keuangan



4 = Informasi non keuangan berguna, bermanfaat untuk mengembangkan ekspektasi

$5=$ Informasi non keuangan menyajikan informasi tambahan yang berguna untuk mengembangkan ekspektasi.

$1=$ Hanya Historical Cost

Seberapa jauh perusahaan

$2=$ Dominan Historical menggunakan

Cost

3 = Fair Value dan Historical Cost seimbang dengan historical cost?

$4=$ Dominan Fair Value

$5=$ Hanya Fair Value

1 = Tidak ada umpan

Seberapa jauh balik informasi dalam 2 = Sedikit umpan balik annual report pada masa lalu memberikan $\quad 3=$ Umpan Balik saat ini umpan balik $4=$ Umpan balik kepada pengguna membantu mengenai peritiwa memahami pasar dan transaksi yang signifikan dapat mempengaruhi perusahaan? bagaimana peristiwa dan transaksi mempengaruhi perusahaan. $5=$ Umpan balik komperhensif

\section{Sumber: Beest (2009). Quality of Financial}

Reporting Measuring Qualitative

Characteristics

\section{Teori Agensi}

Teori agensi merupakan teori mengenai hubungan antara agen dan prinsipal. Jensen dan Meckling (1976) mendefinisikan hubungan keagenan sebagai sebuah kontrak dimana satu atau lebih prinsipal menyewa orang lain (agen) untuk melakukan beberapa jasa demi kepentingan mereka. Pihak agen adalah 
manajemen sementara prinsipal adalah pemegang saham. Agen dan prinsipal memiliki kepentingan yang berbeda dalam memaksimalkan keuntungan perusahaan. Agen memiliki lebih banyak informasi dibandingkan dengan prinsipal sehingga agen cenderung tidak selalu bertindak untuk kepentingan prinsipal (bersifat oportunisik). Informasi yang diungkapkan oleh pihak manajemen akan mempengaruhi kualitas laporan yang dihasilkan sehingga diperlukan pengawasan dari pihak pemegang saham.

\section{Teori Sinyal}

Menurut teori ini, jika manajemen mengharapkan suatu tingkat pertumbuhan perusahaan yang tinggi di masa depan, maka mereka akan berusaha memberikan sinyal itu terhadap investor melalui akun- akun. Teori sinyal memprediksi bahwa perusahaan akan mengungkapkan lebih banyak informasi kepada pengguna dari yang seharusnya diungkapkan. Sinyal yang diungkapkan oleh manajemen dalam laporan keuangan dapat mencerminkan keadaan sebenarnya yang dialami oleh perusahaan dan bisa bersifat positif atau negatif bagi prinsipal. Sinyal yang bersifat positif dapat menguntungkan agen (manajemen) karena prinsipal cenderung akan menambah jumlah investasinya. Sedangkan sinyal yang bersifat negatif akan berakibat sebaliknya.

\section{Determinan Kualitas Laporan Keuangan}

Penelitian ini menggunakan dua teori utama, yaitu teori agensi dan teori sinyal. Teori agensi merupakan teori yang menjelaskan hubungan antara manajemen dan pemegang saham. Teori agensi dalam kaitannya dengan kualitas laporan keuangan adalah manajemen sebagai pengelola perusahaan harus memberikan informasi yang dapat dipertanggung jawabkan, informasi yang disampaikan kepada pemegang saham harus berkualitas, salah satunya memiliki relevansi. Selanjutnya adalah teori sinyal. Dalam teori sinyal, manajemen bermaksud memberikan sinyal kepada pengguna laporan tahunan mengenai keadaan dan kondisi perusahaan. Sinyal ini dapat bersifat positif maupun negatif.

Determinan yang digunakan dalam penelitian ini adalah dengan menggunakan beberapa variabel, yaitu kompetensi komite audit, kepemilikan manajemen dan ukuran dewan komisaris. Sakti (2019) melakukan penelitian mengenai keahlian keuangan komite audit terhadap relevansi laporan keuangan (dengan proksi ketepatan waktu pelaporan keuangan). Dari hasil penelitiannya, dapat disimpulkan bahwa keahlian keuangan memiliki pengaruh positif yang signifikan terhadap ketepatan waktu pelaporan keuangan. Menurut Sakti (2019), komite audit memiliki tugas untuk menganalisis informasi keuangan yang akan diberikan kepada stakeholders. Selain itu, komite audit memiliki peran untuk mengawasi pemeriksaan yang dilakukan oleh auditor internal perusahaan dan memonitor tindak lanjut hasil temuan tersebut. Komite audit yang memiliki keahlian di bidang akuntansi dan keuangan diharapkan akan memiliki kinerja yang efektif.

Semakin besar proporsi kepemilikan manajemen pada perusahaan, maka akan mendorong manajemen untuk bekerja demi kepentingan pemegang saham yang tidak lain adalah dirinya sendiri. Manajemen diharapkan lebih giat dalam memperbaiki kinerjanya sehingga profit yang diperoleh perusahaan akan maksimal. Perusahaan yang memiliki kinerja yang baik, tidak memiliki alasan untuk menyembunyikan informasi seperti informasi mengenai rencana ke depan, risiko dan peluang, serta peristiwa pasar yang mempengaruhi perusahaan kepada stakeholders. Dalam praktiknya, mereka akan menyampaikan laporan keuangan dengan segera dan memberikan informasi umpan balik kepada stakeholders atas peristiwa pasar yang terjadi. Peran Komisaris diperlukan sebagai controller. Selain itu, peran dewan komisaris diharapkan akan meminimalisir masalah agensi yang timbul antara dewan direksi dengan pemegang saham. 
Dari informasi penelitian yang dilakukan oleh Krismiaji (2016) dan (Milawati, Kustina, \& Dewi, 2018) menemukan bahwa ukuran Board Governance memiliki pengaruh yang positif terhadap relevansi informasi akuntansi. Relevansi informasi akuntansi yang digunakan dalam penelitian ini adalah predictive value. Semakin banyak Dewan Komisaris yang terlibat dalam melakukan control maka akan semakin relevan dan cepat penyampaian laporan keuangan yang disajikan kepada pengguna.

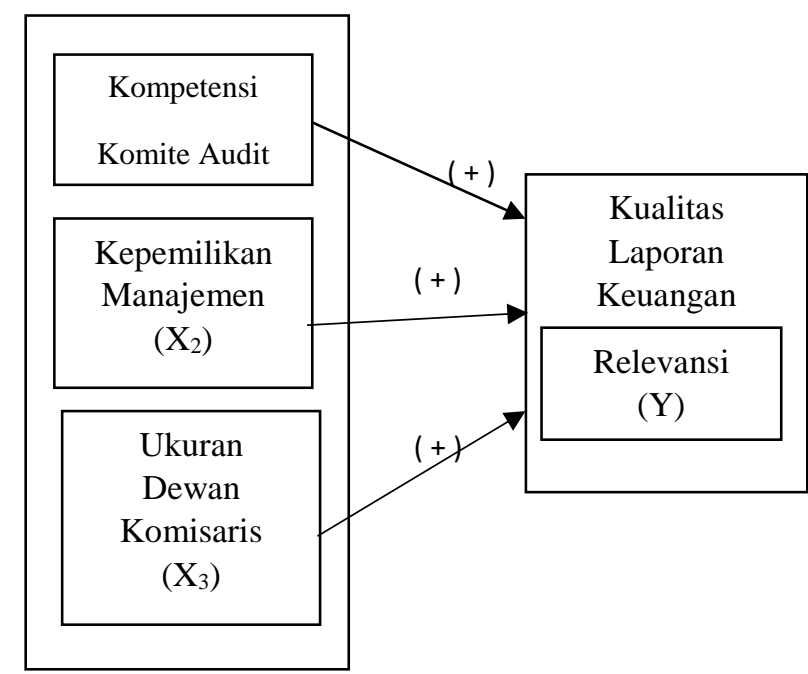

Gambar 2 Kerangka Pemikiran

\section{METODE PENELITIAN}

Studi ini merupakan penelitian hipotesis berupa kausalitas yang bertujuan untuk menguji pengaruh sebab akibat antara dua variabel atau lebih. Penelitian ini menguji hipotesis berdasarkan data dari perusahaan sub sektor makanan dan minuman yang terdaftar di Bursa Efek Indonesia (BEI) pada tahun 2015-2018, sehingga unit analisis yang digunakan adalah kelompok perusahaan.

Populasi yang digunakan dalam penelitian ini adalah perusahaan dalam sub sektor makanan dan minuman yang terdaftar di Bursa Efek Indonesia periode 2015-2018. Teknik sampel yang digunakan dalam penelitian ini adalah purposive sampling, dengan pengambilan sampel sumber data dengan pertimbangan tertentu. Kriteria pemilihan sampel dapat dilihat dalam tabel 2. Total sampel yang digunakan dalam penelitian ini adalah 32 sampel yang terdiri dari delapan perusahaan dengan periode waktu penelitian selama empat tahun. Teknik analisis yang digunakan dalam penelitian ini menggunakan analisis statistik deskriptif dan model regresi data panel.

Tabel 2 Kriteria Pengambilan Sampel

\begin{tabular}{|c|c|c|}
\hline No. & Keterangan & Jumlah \\
\hline 1 & $\begin{array}{l}\text { Perusahaan sub sektor } \\
\text { makanan dan minuman yang } \\
\text { terdaftar di Bursa Efek } \\
\text { Indonesia periode } 2015-2018\end{array}$ & 24 \\
\hline 2 & $\begin{array}{l}\text { Perusahaan sub sektor } \\
\text { makanan dan minuman yang } \\
\text { tidak konsisten menerbitkan } \\
\text { laporan tahunan secara } \\
\text { lengkap periode } 2015-2018\end{array}$ & (8) \\
\hline 3 & $\begin{array}{l}\text { Perusahaan sub sektor } \\
\text { makanan dan minuman yang } \\
\text { tidak memiliki kepemilikan } \\
\text { saham oleh manajemen } \\
\text { periode 2015-2018 }\end{array}$ & (8) \\
\hline & Jumlah Sampel & 8 \\
\hline & Total Observasi $(8 \times 4)$ & 32 \\
\hline
\end{tabular}

Sumber: Data Diolah (2020)

Teknik analisis data yang digunakan menggunakan analisis statistik deskriptif dan model regresi. Persamaan analisis model data panel yang digunakan dalam penelitian ini adalah sebagai berikut:

$R E V=a+\beta 1 C O M+\beta 2 M A N+\beta 3$ SIZE $+e$ (5)

REV = Relevansi Laporan Keuangan

$\alpha=$ Konstanta regresi

$\beta_{1}-\beta_{3}=$ Koefisien regresi masing-masing variabel independen

$\mathrm{COM}=$ Kompetensi Komite Audit 


$$
\begin{array}{ll}
\text { MAN } & =\text { Kepemilikan Manajemen } \\
\text { SIZE } & =\text { Ukuran Dewan Komisaris } \\
\varepsilon_{t} & =\text { Error }
\end{array}
$$

\section{HASIL DAN PEMBAHASAN}

Hasil uji normalitas dengan Kolmogorov Smirnov dapat dilihat pada tabel 3. Dari tabel tersebut dapat dilihat bahwa nilai Asymp. Sig. (2 tailed) sebesar 0,081. Penelitian ini menggunakan taraf signifikansi senilai 0,05 atau $5 \%$. Berdasarkan tabel 3, dapat disimpulkan bahwa nilai Asymp. Sig. berada di atas 0,05.

\begin{tabular}{|c|c|c|}
\hline \multicolumn{3}{|c|}{$\begin{array}{c}\text { Tabel } 3 \text { Hasil Uji Normalitas } \\
\text { Kolmogorov Smirnov }\end{array}$} \\
\hline $\begin{array}{c}\text { Taraf } \\
\text { Signifikansi }\end{array}$ & $\begin{array}{l}\text { Asymp. } \\
\text { Sig }\end{array}$ & Keputusan \\
\hline 0,05 & 0,081 & $\begin{array}{c}\text { Data } \\
\text { Terdistribusi } \\
\text { Normal }\end{array}$ \\
\hline
\end{tabular}
Maka dapat disimpulkan bahwa data terdistribusi secara normal.

Sumber: Data Diolah (2020)

Dari hasil pengolahan data menggunakan SPSS, dapat dilihat dalam tabel 4. berdasarkan tabel tersebut, dapat disimpulkan bahwa semua variabel memiliki nilai tolerance > 0,1 dan VIF < 10, maka dapat disimpulkan bahwa dapat disimpulkan bahwa penelitian ini tidak terdapat multikolinearitas.

Tabel 4 Hasil Uji Multikolinearitas

\begin{tabular}{lccc}
\hline Variabel & TOL & VIF & Simpulan \\
\hline COM & 0,550 & 1,818 & $\begin{array}{c}\text { Tidak Terdapat } \\
\text { multikolinearitas }\end{array}$ \\
MAN & 0,995 & 1,005 & $\begin{array}{c}\text { Tidak terdapat } \\
\text { multikolinearitas }\end{array}$ \\
SIZE & 0,549 & 1,821 & $\begin{array}{c}\text { Tidak Terdapat } \\
\text { multikolinearitas }\end{array}$ \\
\hline
\end{tabular}

Sumber: Diolah oleh Peneliti (2020)

Uji autokorelasi dalam penelitian ini menggunakan uji Durbin Watson. Autokorelasi menunjukkan bahwa ada korelasi antara error dengan error periode. Dari hasil pengolahan, diperoleh nilai Durbin Watson statistic sebesar 0,834 . Dengan jumlah observasi 25 sementara jumlah variabel bebas $(\mathrm{k})$ sebesar 3 dan dengan menggunakan alpha 5\% diperoleh nilai Durbin Watson tabel masing - masing $D_{L}=1,1228$ dan $D_{u}=1,6540$, dapat disimpulkan terdapat autokorelasi positif.

Untuk mengatasi autokorelasi positif, dilakukan uji Run Test. Apabila hasil dari uji Run Test, nilai Asymp. Sig. di atas 0,05 maka tidak terdapat gejala autokorelasi. Hasil uji Run Test dengna Sig. 0,103, tidak terdapat gejala autokorelasi dan uji asumsi klasik selanjutnya dapat dilakukan.

Uji heteroskedastisitas digunakan untuk mengetahui ada atau tidaknya penyimpangan asumsi klasik heteroskedastisitas yaitu adanya ketidaksamaan varian dari residual untuk semua pengamatan dalam model regresi. Dalam penelitian ini, digunakan uji Glejser dalam menguji heteroskedastisitas. Hasil uji heteroskedastisitas dapat dilihat dalam tabel 5 . Dari tabel 5 dapat disimpulkan bahwa tidak terdapat heteroskedastisitas.

Tabel 5 Hasil Uji Heteroskedastisitas

\begin{tabular}{lcc}
\hline Variabel & Sig. & Kesimpulan \\
\hline COM & 0,542 & $\begin{array}{c}\text { Tidak ada } \\
\text { heteroskedastisitas } \\
\text { Tidak ada } \\
\text { MAN }\end{array}$ \\
SIZE & 0,089 & $\begin{array}{c}\text { heteroskedastisitas } \\
\text { Tidak ada } \\
\text { heteroskedastisitas }\end{array}$ \\
\hline
\end{tabular}

Sumber: Data Diolah (2020)

Hasil nilai Adjusted R-Square sebesar 0,621 atau $62,1 \%$ yang berarti bahwa variabel independen dalam penelitian ini dapat menjelaskan variabel dependen sebesar $62,1 \%$, sedangkan sisanya sebesar $37,9 \%$ dipengaruhi oleh variabel lain yang tidak masuk dalam penelitian ini. 
Tabel 6 Hasil Uji Statistik F dan $\mathbf{t}$

\begin{tabular}{lcccc}
\hline Variabel & $\mathbf{B}$ & $\mathbf{t}$ & $\begin{array}{c}\text { Sig. } \\
\text { One } \\
\text { Tailed }\end{array}$ & Kesimpulan \\
\hline COM & $-2,378$ & $-2,352$ & 0,0145 & Ha diterima \\
MAN & 0,046 & 0,295 & 0,3855 & Ha ditolak \\
SIZE & 5,919 & 5,607 & 0,000 & Ha diterima \\
F Test & 14,088 & & & \\
Sig. & 0,000 & & & \\
\hline
\end{tabular}

Sumber: Data Diolah (2020)

Uji parsial digunakan untuk menguji pengaruh variabel kompetensi komite audit, kepemilikan manajemen, dan ukuran dewan komisaris secara individual terhadap kualitas laporan keuangan (dengan proksi relevansi laporan keuangan). Hasil uji t dapat dilihat pada tabel 5. Berdasarkan tabel tersebut, maka dapat disimpulkan:

1. Nilai sig. variabel kompetensi komite audit sebesar 0,0145 $<0,05$ dengan koefisien sebesar $-2,378$ sehingga dapat disimpulkan bahwa kompetensi komite audit memiliki pengaruh signifikan arah negatif terhadap kualitas laporan keuangan.

2. Nilai sig. variabel kepemilikan manajemen sebesar 0,3855 > 0,05 sehingga dapat disimpulkan bahwa kepemilikan manajemen tidak memiliki pengaruh signifikan terhadap kualitas laporan keuangan.

3. Nilai sig, variabel ukuran dewan komisaris sebesar 0,000 $<0,005$ dengan koefisien sebesar 5,919, yang dapat menunjukkan bahwa terdapat pengaruh signifikan arah positif ukuran dewan komisaris terhadap kualitas laporan keuangan.

\section{Pengaruh Kompetensi Komite Audit Terhadap Kualitas Laporan Keuangan}

Komite audit memiliki peran yang penting dalam menerapkan Good Corporate Governance di perusahaan. Dalam Peraturan Otoritas Jasa Keuangan No. 55 Pasal 7 dijelaskan bahwa komite audit wajib memahami laporan keuangan, bisnis perusahaan, proses audit dan manajemen risiko. Untuk memiliki pemahaman tersebut, seorang komite audit harus memiliki latar belakang pendidikan atau pengalaman di bidang akuntansi, audit atau keuangan.

Berdasarkan tabel 6 dapat disimpulkan bahwa kompetensi komite audit memiliki pengaruh yang signifikan arah negatif terhadap kualitas laporan keuangan (dengan proksi relevansi laporan keuangan), artinya semakin banyak komite audit yang memiliki kompetensi maka semakin sedikit atau turun kualitas laporan keuangannya. Hal ini sesuai dengan penelitian yang dilakukan oleh Sunarsih dan Dewi (2019). Komite audit yang memiliki latar belakang dan pengalaman di bidang akuntansi, audit dan keuangan tidak menjamin laporan keuangan berkualitas. Semakin banyak komite audit yang memiliki kompetensi maka semakin banyak pihak yang memiliki tindakan oportunis untuk menguntungkan dirinya sendiri. Tindakan oportunis akan semakin besar dilakukan oleh mereka ketika mereka memiliki pengetahuan yang mumpuni di bidang akuntansi, audit atau keuangan.

\section{Pengaruh Kepemilikan Manajemen dan Terhadap Kualitas Laporan Keuangan \\ Selain pemerintah, manajemen} terutama Senior Manager dapat memiliki peran dalam keputusan yang akan diambil oleh perusahaan. Saat ini bonus yang diberikan oleh perusahaan dapat berupa kepemilikan saham. Semakin besar persentase kepemilikan saham, maka akan semakin besar peran manajer tersebut. Penelitian yang dilakukan oleh Harnida (2015) menyimpulkan bahwa kepemilikan manajemen memiliki pengaruh yang positif terhadap penyampaian waktu laporan keuangan. Semakin tinggi jumlah kepemilikan manajemen maka semakin perusahaan akan menyampaikan laporan keuangan dengan segera.

Berdasarkan tabel 6 dapat disimpulkan bahwa tidak terdapat pengaruh kepemilikan amanjemene terhadap kualitas laporan keuangan. Kepemilikan manajemen di 
perusahaan yang menjadi sampel, terbilang paling rendah jika dibandingkan dengan kepemilikan institusional dan masyarakat. Rata - rata kepemilikan manajemen hanya berkisar 0,06883 atau $6,883 \%$.

\section{Pengaruh Ukuran Dewan Komisaris Terhadap Kualitas Laporan Keuangan}

Salah satu asas Corporate Governance adalah akuntabilitas (tanggung jawab). Komisaris diberikan tanggung jawab oleh pemilik untuk melakukan kontrol perusahaan. Semakin besar jumlah board yang ada di suatu perusahaan maka akan semakin banyak pemikiran untuk melakukan kontrol yang efektif terhadap Direksi. Direksi sebagai pihak yang menjalankan kegiatan operasional perusahaan, perlu untuk menginformasikan laporan keuangan yang dapat dipahami dan tepat waktu.

Peran Komisaris diperlukan sebagai controller. Selain itu, peran dewan komisaris diharapkan akan meminimalisir masalah agensi yang timbul antara dewan direksi dengan pemegang saham. Berdasarkan tabel 6 dapat disimpulkan bahwa terdapat pengaruh positif antara ukuran dewan komisaris dan kualitas laporan keuangan. Hal ini sesuai dengan penelitian yang dilakukan oleh Krismiaji (2016) dan (Milawati, Kustina, \& Dewi, 2018) yang menemukan bahwa ukuran Board Governance memiliki pengaruh yang positif terhadap relevansi informasi akuntansi. Relevansi informasi akuntansi yang digunakan dalam penelitian ini adalah predictive value. Semakin banyak Dewan Komisaris yang terlibat dalam melakukan control maka akan semakin relevan dan cepat penyampaian laporan keuangan yang disajikan kepada pengguna.

\section{PENUTUP}

Berdasarkan hasil penelitian mengenai pengaruh kompetensi komite audit, kepemilikan manajemen dan ukuran dewan komisaris terhadap kualitas laporan keuangan, maka dapat diambil beberapa kesimpulan sebagai berikut:

1. Kompetensi komite audit secara parsial memiliki pengaruh negatif terhadap kualitas laporan keuangan

2. Kepemilikan manajemen secara parsial tidak memiliki pengaruh terhadap kualitas laporan keuangan

3. Ukuran dewan komisaris secara parsial memiliki pengaruh positif terhadap kualitas laporan keuangan

Berdasarkan pada hasil penelitian, saran yang dapat disampaikan terkait pengaruh kompetensi komite audit, kepemilikan manajemen dan ukuran dewan komisaris terhadap kualitas laporan keuangan adalah sebagai berikut:

1. Saran Praktis

Berdasarkan hasil penelitian ini, diharapkan menjadi acuan bagi manajemen dalam menjaga kualitas laporan keuangan (terutama relevansi) untuk pengguna laporan keuangan. Pihak manajemen juga kiranya lebih memperhatikan penerapan tata kelola perusahaan yang baik guna meningkatkan kepercayaan investor dan para pengambil keputusan terhadap informasi yang disajikan dalam laporan keuangan.

2. Saran bagi Penelitian Selanjutnya

Dari segi kualitas laporan keuangan, bagi peneliti selanjutnya dapat menggunakan pengukuran lain selain yang digunakan dalam penelitian ini untuk mengukur kualitas laporan keuangan. Sehingga, dapat memperkaya pengetahuan terkait dengan kualitas laporan keuangan. 


\section{REFERENCES:}

Chrisdianto, Bernadinus. 2013. Peran Komite Audit dalam Good Corporate Governance. Jurnal Akuntansi Aktual, 2 (1): 1-8.

Financial Accounting Standards Board (FASB). 1980. Statement of Financial Accounting Concepts No. 2: Qualitative Characteristics of Accounting Information.

Harnida, Muthia. 2015. Pengaruh Mekanisme Corporate Governance Terhadap Ketepatan Waktu Penyampaian Laporan Keuangan : Studi Empiris Pada Perusahaan Publik yang Terdaftar di Bursa Efek Indonesia. JSAI, 2 (1): 25-36.

Jao, Robert dan Gagaring Pagalung, 2011. Corporate Governance, Ukuran Perusahaan, dan Leverage Terhadap Manajemen Laba Perusahaan Manufaktur Indonesia. Jurnal Akuntansi \& Auditing, 8 (1): 43-94.

Jensen, M., dan Meckling, W. 1976. Theory of the Firm: Managerial Behavior, Agency Costs and Ownership Structure. Journal of Financial Economics: 305-360.

Komite Nasional Kebijakan Governance (KNKG). 2006. Pedoman Umum Good Corporate Governance Indonesia, Jakarta.

Kartikahadi, Hans, Rosita Uli Sinaga, Merliyana Syamsul, Sylivia Veronica Siregar dan Ersa Tri Wahyuni. 2016. Akuntansi Keuangan Berdasarkan SAK Berbasis IFRS. Edisi Kedua. Jakarta: Ikatan Akuntan Indonesia.

Krismiaji, Y. Anni Aryani dan Djoko Suhardjanto. 2016. International Financial Reporting Standards, Board Governance, and Accounting Quality. Asian Review Accounting, 24 (4): 474-497.

Milawati, Gine Das Prena, Ketut Tanti Kustina dan I Gusti Ayu Agung Omika Dewi. 2018. Pengaruh Ukuran Perusahaan, Jumlah Komisaris Independen, dan Biaya CSR Terhadap Kecepatan Pelaporan Keuangan Pada Perusahaan Otomotif dan Komponen yang Terdaftar di Bursa Efek Indonesia. Jurnal Ilmiah Akuntansi \& Bisnis, 3 (1): 1-11.

Peraturan Otoritas Jasa Keuangan No. X.K.2 Tentang Penyampaian Laporan Keuangan Berkala Emiten atau Perusahaan Publik diunduh dari www.eodb.ekon.go.id.

Peraturan Otoritas Jasa Keuangan No. 55/POJK.04/2015 Tentang Pembentukan dan Pedoman Pelaksanaan Kerja Komite Audit diunduh dari www.eodb.ekon.go.id.

Putri, Bunga Pramudia. 2015. Pengaruh Karakteristik Komite Audit, Fee Audit, Ukuran KAP, dan Internal Auditor Terhadap Ketepatan Waktu (Timeliness) Pelaporan Keuangan (Studi Empiris pada Perusahaan yang Listing di BEI tahun 2013). Jom FEKON, 2 (2).

Sakti, Wisnu Orima dan Fuad. 2019. Pengaruh Karakteristik Komite Audit Terhadap Waktu Pelaporan Keuangan. Diponegoro Journal of Accounting, 2 (4): 1-9

Sunarsih, Ni Made dan Ni Putu Shinta Dewi. 2019. Pengaruh Karakteristik Komite Audit Terhadap Ketepatan Waktu Pelaporan Keuangan Perusahaan Perbankan yang Terdaftar di BEI. Juima, 9 (1) : $13-20$

Undang - Undang No. 40 Tahun 2007 Tentang Perseroan Terbatas diunduh dari www.ojk.go.id/sustainable-finance/id

Wareza, Monica. (2019, Jul, 7). Kisah TPS Food, Berapa Lama 'Luka' Ini Sembuh?.www.cnbcindonesia.com 
